\title{
Determinants of Millenial Generations Interest In Using Mobile Banking
}

\author{
Sarmiana Batubara ${ }^{1}$, Ihdi Aini², Yuli Agustina ${ }^{3}$ \\ Email: 1sarmianabatubara12@gmail.com, 2ihdi.aini@yahoo.co.id, \\ 3yuliagustina615@gmail.com \\ 1,2,3Institut Agama Islam Negeri Padangsidimpuan \\ Jl. H.T. Rizal Nurdin Km. 4,5 Sihitang, Padangsidimpuan
}

\begin{abstract}
Abstrak
Layanan mobile banking yang dikeluarkan oleh dunia perbankan, ditujukan untuk memudahkan nasabah dalam melakukan transaksi yang didukung oleh telepon seluler dan jaringan internet. Meski begitu, masih banyak nasabah yang belum menggunakan mobile banking, khususnya mobile banking syariah, termasuk dari generasi milenial yang seharusnya lebih mudah menerima perubahan dan generasi milenial lebih melek teknologi dan mudah menguasai teknologi. Dalam kegiatan ekonomi generasi milenial, banyak transaksi yang dilakukan secara online, mulai dari berbelanja di marketplace, media sosial dan media elektronik lainnya. Penelitian ini bertujuan untuk mengetahui faktor-faktor yang mempengaruhi minat generasi milenial dalam menggunakan mobile banking pada bank syariah. Penelitian ini merupakan penelitian kuantitatif. Sumber data yang digunakan adalah data primer. Teknik pengumpulan data yang digunakan adalah wawancara dan angket. Responden dalam penelitian ini adalah generasi millennial sebanyak 93 orang. Hasil dari penelitian terdapat beberapa faktor yang mempengaruhi minat generasi milenial dalam menggunakan mobile banking bank syariah yaitu faktor kenyamanan, manfaat, kepercayaan dan risiko. Berdasarkan hasil analisis data, faktor kenyamanan, manfaat, kepercayaan dan risiko berpengaruh terhadap minat generasi milenial dalam menggunakan mobile banking di bank syariah baik secara parsial maupun simultan.
\end{abstract}

Kata kunci: Determinan, Generasi Milenial, Mobile Banking

\begin{abstract}
Mobile banking services issued by the banking world, are aimed at making it easier for customers to make transactions that are supported by mobile phones and internet networks. Even so, there are still many customers who have not used mobile banking, especially Islamic mobile banking, including those from the millennial generation who should be more receptive to change and the millennial generation is more technology literate and easy to master technology. In the economic activities of the millennial generation, many transactions are online, starting from shopping on the marketplace, social media and other electronic media. This study aims to determine the factors that influence the interest of the millennial generation in using mobile banking at Islamic banks. This research is a quantitative research. The data source used is primary data. The data collection techniques used were interviews and questionnaires. Respondents in this study were the millennial generation as many as 93 people. The results of this study are that there are several factors that influence the interest of the millennial generation in using Islamic bank mobile banking, namely the factors of convenience, benefits, trust and risk. Based on the results of data analysis that has been carried out, the factors of convenience, benefits, trust and risk have an effect on the interest of the millennial generation in using mobile banking at Islamic banks both partially and simultaneously.
\end{abstract}

Keywords: Determinants, Millennial Generation, Mobile Banking 


\section{Determinants Of Millenial Generations \\ Interest In Using Mobile Banking \\ Sarmiana Batubara, dkk.}

\section{Introduction}

The rapid advancement of computer technology in hardware, software, network systems and data communication has had a tremendous impact on electronic Islamic banking services. The development of Electronic Banking (E-Banking) has taken a big leap, bank transactions have become easy, fast and real time without any time and place restrictions. Mobile banking cannot run if it is not supported by cellphones or cellphones and the internet, everyone who has a cellphone can take advantage of this facility to make transactions anywhere and anytime while there is still an internet connection. E-banking services, especially mobile banking, meet the demands and needs of customers as an alternative medium for banking transactions, customers do not have to come to the bank or to an ATM, except for deposit and withdrawal transactions for cash. (Supriyono, 2010)

The development of banking, both conventional and Islamic banks, provides and offers convenience to customers through a wide variety of operational services, including E-Banking services. E-Banking services are currently owned by all existing commercial banks including Islamic banks, the Financial Services Authority or (OJK) explains that E-banking is a service that allows bank customers to obtain information, communicate and conduct banking transactions via electronic media such as ATM, internet banking. , sms banking, mobile banking, phone banking and video banking. (Arumi \& Heri Yanto, 2019)

According to the Ministry of Communication and Information Technology, Indonesia's population of 250 million people and smartphone or cellphone users in Indonesia are also growing rapidly, the digital marketing research institute estimates that the number of active smartphone users in Indonesia is more than 100 million. With such a large number, Indonesia will become the fourth largest active smartphone user country after China, India and America. (Kominfo, 2021)

Report from the Association of Indonesian Internet Service Providers (APJII) in the secretary general of APJII Henri Kasyfi Soemartono in Jakarta, there are $\mathbf{1 7 1 . 1 7}$ million Indonesian internet users. When talking about age, the most internet users are Millennials, 20-24 years with 88.5 percent penetration then 25-29 years with 82.7 percent penetration in the 30-34 year group with 76.5 percent penetration and the 35-39 age group year with a penetration of 68.5 percent. (Haryanto, 2019)

It turns out that the survey proves, the type of service accessed by the most users is chatting with 89.35 percent, followed by social media 87.13 , then followed by 
seeing photos of 72.79 percent, at least for banks, the results of this survey state that only 7.39 percent of respondents access banking services via the internet. According to a report by international consultant service PWC (Price Water House Cooper), Indonesia has around 132 million internet users with 178 million mobile users and 120 million active mobile social media users. This figure is combined with more than 50 million smartphone users. (Asosiasi Penyelenggara Jasa Internet Indonesia, 2018)

Picture 1

Mobile Banking Berbasis Smartphone Is A Major Component Of A Digital Strategy

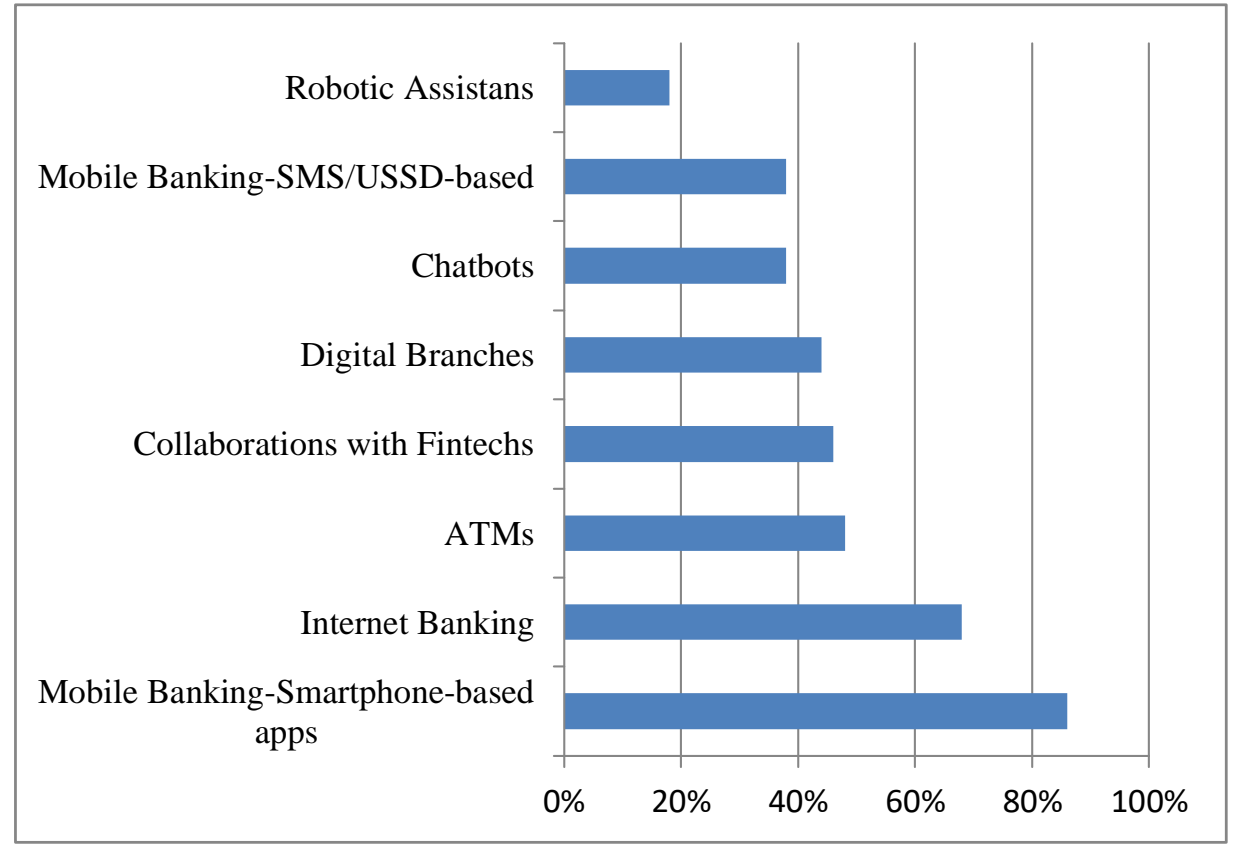

Source :PWC Survey digital banking in Indonesia (2018)

From the picture above, mobile banking users in Indonesia are the highest in digital banking strategies at 86 percent when compared to others such as internet banking around 68 percent, ATM around 48 percent, collaborations with fintechs around 46 percent, digital branches around 44 percent, chatbots around 38 percent, mobile banking-sms / ussd-based around 38\% and robotic assistance around $18 \%$.

The development of technology allows everyone to easily carry out banking transactions. The presence of mobile banking at Islamic banks is certainly very helpful in facilitating the needs of its users, but the high number of crimes in the banking world will certainly be something that we really need to pay attention to, where if we are really used to using various kinds of banking applications. The use of mobile banking at Islamic banks will be difficult to avoid because this application provides many conveniences in various financial transactions. Given the high risk in its use, we must pay attention properly to how to use and also anticipate various 


\section{Determinants Of Millenial Generations \\ Interest In Using Mobile Banking}

Sarmiana Batubara, dkk.

criminal acts in mobile banking. This will help us to secure accounts and various kinds of information and funds contained in them.

Millennial generation is usually referred to as generation Y. This grouping is actually calculated from the year of birth and the millennial generation can be representative of people born in the 1981-1996 range, while those born in 1997 and above are grouped into generation $\mathrm{Z}$. The character of the millennial generation is starting from a faster way of working, sharing useful information on social media. (Amira \& Juliani, 2019)

Another character of the millennial generation is self-confidence and thirst for attention, in this era besides computers, the internet has also become commonplace, even the millennial generation can be said that they cannot live without an internet connection. (Rahmawati, 2018)

Even though there are many benefits obtained by customers, in fact, many customers who have not used mobile banking at Islamic banks are among the millennial generation who are more receptive to change and more technologically literate and easy to master technology. In the economic activities of the millennial generation, many transactions are online, starting from shopping on the marketplace, social media and other electronic media. The millennial generation is not used to doing transactions with mobile banking and even there are still many who do not understand and do not understand using the mobile banking application.

An interview conducted with one of the millennial generation or student named Adelinda Hutasuhut Faculty of Da'wah and Communication Sciences IAIN Padangsidimpuan said that he still checks the balance manually if his parents send him monthly money. Another interview with Duma Sari Siregar, Faculty of Economics and Islamic Business IAIN Padangsidimpuan, he said that he did not understand about transacting using mobile banking. One of the factors is the limited information regarding the existence of mobile banking at Islamic banks and its advantages. Customers or millennial generation do not understand what products are contained in mobile banking at Islamic banks.

Based on the description above, the researcher used 4 independent variables in this study, namely the convenience, benefit, trust and risk factors, while the dependent variable was interest. Thus, the problem formulation in this study is whether there is an influence of convenience, benefit, trust and risk factors partially 
influencing the interest of the millennial generation in using mobile banking at Islamic banks.

\section{Literature Review}

\section{Interest}

Interest in the large Indonesian dictionary is defined as a tendency towards a high heart towards something. Interest is a mental device consisting of a mixture of feelings, hopes, convictions, prejudices, fears or other tendencies that lead the individual to a certain choice (Mappiare, 1982). Several factors influence interest namely: differences in employment, differences in socioeconomic, age differences, cultural factors, social factors, personal factors, and psychological factors (Hasibuan, 2008).

\section{Convenience}

Ease is the perception that ease of use means an individual's belief that the use of information technology systems will not be a hassle or require a lot of effort when used (Yani dkk., 2018). Ease of use is defined as the extent to which someone believes that using a technology will be free from effort. If someone believes that a system is easy to use then this is a belief about the decision making process (Dewi \& Warmika, 2016).

Ease in terms of mobile banking is a person's belief that in using mobile banking it can be easily understood and used. Ease in terms of mobile banking is a person's belief that in using mobile banking it can be easily understood and used. Thus, if someone uses a certain system, it will work more easily than someone who works manually.

The ease of mobile banking users means that customers find transactions via mobile banking easy to understand, if mobile banking is easy to understand then the service is easy to use and will often be used by customers. On the other hand, if mobile banking is not easy to understand, the service will not attract or attract customers to use it. If customers think that mobile banking services do not require much effort and when using these services they feel that the desired job will be easier, then mobile banking will often be used by customers as well. 


\section{Determinants Of Millenial Generations \\ Interest In Using Mobile Banking \\ Sarmiana Batubara, dkk.}

\section{Benefits}

Benefit is a measure whereby the use of a technology is believed to benefit the people who use it. The subjective ability of users in the future by using a specific application system will improve performance in an organizational context. Benefits is defined as a measure by which the use of technology is believed to bring benefits to the people who use it. From the description above, we can conclude that benefits are a result that is felt and obtained from using a system (Nofitasari, 2017).

A person uses mobile banking services if that person believes that mobile banking can provide benefits to their work and their work achievements. Customers who use mobile banking hope to get benefits, when performing their duties and routine work after using mobile banking. The measurement of the benefit is based on the frequency of use of the application being run.

Mobile banking services will be useful if they are easy to understand and are able to establish interactions with users. The use of mobile banking for customers can save time and money because customers do not have to go to the bank directly just to make transactions, because mobile banking provides 24-hour service. Customers can make transactions anytime and anywhere as long as there is an internet network even when the bank office is closed.

\section{Trust}

Trust is the process of forming trust in and a person towards a service based on a known (cognitive) understanding of the service delivery. Consumer trust in using information technology in conducting a transaction is the first step for someone to create interest through the convenience that someone will get to carry out a transaction that will be carried out. Various company efforts to provide this trust are directly related to efforts to create customer satisfaction (Sugara \& Dewantara, 2017).

Based on the above definition, it can be concluded that a customer's trust in mobile banking will be formed based on his understanding of the service. A customer's trust in mobile banking in conducting transactions can create interest through the convenience provided by the system to a customer who is making a transaction. 


\section{Risk}

The definition of risk in general is the possibility of unwanted things that cause losses. Risk is defined as the chance of an unwanted outcome so risk is only associated with situations where a negative outcome is likely to arise and is related to the ability to predict a negative outcome (Basyaib, 2007).

Risk is considered as an uncertainty about the possible negative consequences of using a product or service. If the risk dominates rather than the benefits obtained, the customer will not be interested in using the product or service. Conversely, when the risk to be obtained is getting smaller, the more likely it is that customers will be attracted to use the product or service (Fullah \& Candra, 2012).

Risk is something people consider ineffective to decide or not to do online transactions. It can be said that online transactions carry a high risk, because customers cannot make face-to-face transactions and they also cannot confirm whether the transactions they have done have been processed in a timely manner or not. Before using mobile banking services, customers must have considered various possible risks.

\section{Mobile Banking}

Mobile banking is a facility from banks, both conventional and Islamic banks, in this modern era that follows the development of technology and communication. Services contained in Islamic bank mobile banking are transaction services. The use of sharia bank mobile banking services on cellular phones allows customers to more easily carry out their banking activities without time and space limits. Mobile banking is a service facility that provides easy access and speed in obtaining the latest information and financial transactions in real time. Mobile banking can be accessed by individual customers via cell phones that have GPRS technology. Mobile banking service products are bank distribution channels for accessing accounts held by customers through GPRS technology by means of cellular telephones (Maulana dkk., 2019).

\section{Islamic banking}

Sharia banking is everything concerning Islamic banks and sharia business units, including institutions, business activities, and methods and processes for carrying out their business activities. Islamic banks have the function of collecting 


\section{Determinants Of Millenial Generations \\ Interest In Using Mobile Banking \\ Sarmiana Batubara, dkk.}

funds from the public in the form of deposits and investments from the owner of the funds. Another function is to channel funds to other parties who need funds in the form of buying and selling or business cooperation. Islamic banks do not charge interest and do not pay interest to customers, the benefits received by Islamic banks and those paid to customers depend on the contract and agreement between the customer and the bank (Ismail, 2013).

\section{Millennial Generation}

Millennial generation is usually referred to as generation $Y$. This grouping is actually calculated from the year of birth and the millennial generation can be representative of people born in the 1981-1996 range, while those born in 1997 and above are grouped into generation $\mathrm{Z}$. The character of the millennial generation is starting from a faster way of working, sharing useful information on social media. Another characteristic of the millennial generation is self-confidence and thirst for attention. In this era, besides computers have mushroomed, the internet has also become commonplace, even the millennial generation can be said that they cannot live without an internet connection (Amira \& Juliani, 2019).

Generation Y or millennials should have mobile banking or at least have an interest in using mobile banking because in this millennial era cellphones and internet networks have mushroomed, even every millennial generation is likely to already have cellphones and without cellphones and internet, this mobile banking does not can run smoothly.

\section{Methods}

This type of research is a type of quantitative research. Quantitative research can be defined as a research method based on the philosophy of positivism, used to research on a specific population or sample. The sampling technique is generally carried out by means of probability sampling, data collection is quantitative statistics with the aim of testing predetermined hypotheses (Sugiyono, 2012).

The population in this study were the millennial generation born in 1993 to 1996, the are NIM 2014 and 2015 students of the Padangsidimpuan State Islamic Institute, with a total of 1241 people and more details can be seen in the following table. 


\section{Table 1}

\section{Number of Students of the State Islamic Institute of Padangsidimpuan} NIM 2014 and 2015

\begin{tabular}{|l|l|l|l|l|}
\hline No & \multicolumn{1}{|c|}{ Faculty } & $\begin{array}{c}\text { Number of } \\
\text { Students NIM } \\
2014\end{array}$ & $\begin{array}{c}\text { Number of } \\
\text { Students NIM } \\
2015\end{array}$ & \multicolumn{1}{|c|}{ Total } \\
\hline 1. & Ekonomi dan Bisnis Islam & 95 Students & 471 Students & 566 Students \\
\hline 2. & Syariah dan Ilmu Hukum & 38 Students & 73 Students & 131 Students \\
\hline 3. & $\begin{array}{l}\text { Dakwah dan Ilmu } \\
\text { Komunikasi }\end{array}$ & 64 Students & 102 Students & 166 Students \\
\hline 4. Ilmu & $\begin{array}{l}\text { Tarbiyah dan } \\
\text { Keguruan }\end{array}$ & 90 Students & 308 Students & 398 Students \\
\hline \multicolumn{2}{l|}{ Total } & 287 Students & 954 Students & 1241 Students \\
\hline
\end{tabular}

Source: Academic and Student Affairs BIRO AUAK IAIN Padangsidimpuan (2019)

Sampling is done with the consideration that the existing population is very large in number, so it is not possible to study the entire population. To find out the sample to be studied in this study, the researcher used the Slovin formula or method with an error rate of $10 \%$, the samples in this study were:

$$
\begin{aligned}
& n=\frac{N}{1+N e^{2}} \\
& n=\frac{1241}{1+1241\left(0,1^{2}\right)}=92.54
\end{aligned}
$$

So the sample in this study was 92.54 respondents and was fulfilled to be 93 respondents.

Where :

$$
\begin{array}{ll}
\mathrm{n} & =\text { sample size } \\
\mathrm{N} & =\text { population size } \\
\mathrm{e} & =\text { error received } 10 \%(0,1)
\end{array}
$$

The sampling technique in this study is to use probability sampling techniques. Probability sampling is a sampling technique that provides equal opportunities for each element (member) of the population to be selected as members of the sample. The sampling method in this study used stratified sampling. Stratified sampling is used when in the population there are groups of subjects from one group to another, it appears that there are strata or levels (Arikunto, 2003).

Sampling in this study using a formula: $\mathrm{ni}=\frac{N i}{N} \cdot \mathrm{n}$

Where: 


\section{Determinants Of Millenial Generations \\ Interest In Using Mobile Banking \\ Sarmiana Batubara, dkk.}

ni $\quad=$ Number of samples per level.

$\mathrm{Ni} \quad=$ Number of population per level.

$\mathrm{N} \quad=$ Total population.

$\mathrm{n} \quad=$ The total number of sample members.

Sources of research data can be classified into primary and secondary data sources, without any intermediaries. In this study, the data source used was primary data. Primary data is data that is directly obtained from the first data source at the research location or research object. Secondary data is primary data that has been further processed and has been presented by other parties, for example in the form of tables or in the form of diagrams (Bungin, 2006).

The data collection methods in this research are interviews and questionnaires, then after the data is collected, data analysis will be carried out using SPSS version 23.

\section{Discussion}

This study aims to analyze the determinants of millennial generation's interest in using mobile banking at Islamic banks. To achieve this goal, various data tests were carried out on the data obtained from the field. The data analysis used is the validity test, reliability test, normality test, classical assumption test, multiple linear regression analysis, the coefficient of determination and hypothesis testing.

\section{Validity Test Results}

The validity test is done by comparing the rcount value with the rtable value. Where rtabel is sought at a significance of $10 \%$ or 0.10 with degrees of freedom $(\mathrm{df})=\mathrm{n}-2$, so $\mathrm{df}=93^{-2}=91$. If rcount $>$ rtable and the value of $\mathrm{r}$ is positive, the statement item is said to be valid.

\section{Table 2}

Ease of Validity Test Results

\begin{tabular}{|c|c|c|c|}
\hline $\begin{array}{c}\text { Question } \\
\text { item }\end{array}$ & $\mathbf{r}$ hitung & $\mathbf{r}$ table & $\begin{array}{c}\text { Informati } \\
\text { on }\end{array}$ \\
\hline Kd-1 & 0,684 & \multirow{4}{*}{$\begin{array}{l}\text { The instrument is valid if } \\
\qquad \begin{array}{l}r_{\text {hitung }}>\mathrm{r} \text { tabel } \mathrm{n}=91 \\
\text { At the } 10 \% \text { significance level, } \\
\text { it is obtained } \mathrm{r}_{\text {tabel }}=0,1716\end{array}\end{array}$} & Valid \\
\hline $\mathrm{Kd}-2$ & 0,750 & & Valid \\
\hline Kd-3 & 0,727 & & Valid \\
\hline $\mathrm{Kd}-4$ & 0,698 & & Valid \\
\hline
\end{tabular}

Source: Output of SPSS version 23 (data processed, 2019) 
Based on the table above, it can be seen that the item convenience variable statement is valid. Where $\mathrm{r}$ table is 0.1716 while rcount can be seen in the results of the Corrected Item-Total Correlation and the value of $\mathrm{r}$ is positive.

Table 3

Benefit Validity Test Results

\begin{tabular}{|c|c|c|c|}
\hline $\begin{array}{c}\text { Question } \\
\text { item }\end{array}$ & $\begin{array}{c}\mathbf{r} \\
\text { hitung }\end{array}$ & $\mathbf{r}$ table & $\begin{array}{c}\text { Informatio } \\
\mathbf{n}\end{array}$ \\
\cline { 1 - 2 } Mf-1 & 0,764 & $\begin{array}{c}\text { The instrument is valid if } \\
\text { rhitung }>\mathrm{r}_{\text {tabel }} \mathrm{n}=91\end{array}$ & Valid \\
\cline { 1 - 2 } Mf-2 & 0,666 & Valid \\
\cline { 1 - 1 } Mf-3 & 0,791 & $\begin{array}{c}\text { At the 10\% significance } \\
\text { level, it is obtained } \mathrm{r} \text { tabel }=\end{array}$ & Valid \\
\cline { 1 - 2 } Mf-4 & 0,500 & Valid \\
\hline
\end{tabular}

Source: Output of SPSS version 23

Based on Table above, it can be seen that the item benefit variable statement is valid. Where $\mathrm{r}_{\text {table }}$ is 0.1716 while $\mathrm{r}_{\text {count }}$ can be seen in the results of the Corrected Item-Total Correlation and the value of $r$ is positive.

Table 4

Trust Validity Test Results

\begin{tabular}{|c|c|c|c|}
\hline $\begin{array}{c}\text { Question } \\
\text { item }\end{array}$ & $\mathbf{r}_{\text {count }}$ & $\mathbf{r}_{\text {table }}$ & $\begin{array}{c}\text { Informatio } \\
\mathbf{n}\end{array}$ \\
\hline Kp-1 & 0,667 & \multirow{4}{*}{$\begin{array}{l}\text { The instrument is valid if } \\
r_{\text {count }}>r_{\text {table }} n=91 \\
\text { At the } 10 \% \text { significance } \\
\text { level, the obtained } r_{\text {table }}= \\
0.1716\end{array}$} & Valid \\
\hline Kp-2 & 0,733 & & Valid \\
\hline Kp-3 & 0,622 & & Valid \\
\hline Kp-4 & 0,752 & & Valid \\
\hline
\end{tabular}

Sumber: Hasil Output SPSS versi 23

Based on Table above, it can be seen that the confidence variable statement item is valid. Where $r_{\text {table }}$ is 0.1716 while $r_{\text {count }}$ can be seen in the results of the Corrected Item-Total Correlation and the value of $r$ is positive.

Table 5

Risk Validity Test Results

\begin{tabular}{|c|c|c|c|}
\hline $\begin{array}{c}\text { Question } \\
\text { item }\end{array}$ & $\mathbf{r}_{\text {count }}$ & rtable & $\begin{array}{c}\text { Informatio } \\
\mathbf{n}\end{array}$ \\
\hline Rs-1 & 0,713 & \multirow{4}{*}{$\begin{array}{l}\text { The instrument is valid if } \\
r_{\text {count }}>r_{\text {table }} n=91 \\
\text { At the } 10 \% \text { significance } \\
\text { level, the obtained } r \text { table }= \\
0.1716\end{array}$} & Valid \\
\hline Rs-2 & 0684 & & Valid \\
\hline Rs-3 & 0,771 & & Valid \\
\hline Rs-4 & 0,716 & & Valid \\
\hline
\end{tabular}

Source: Output of SPSS version 23 


\section{Determinants Of Millenial Generations \\ Interest In Using Mobile Banking \\ Sarmiana Batubara, dkk.}

Based on Table above, it can be concluded that the risk variable statement item is valid. Where $r_{\text {table }}$ is 0.1716 while $r_{\text {count }}$ can be seen in the results of the Corrected Item-Total Correlation and the value of $r$ is positive.

Table 6

Result of Millennial Generation Interest Validity Test

\begin{tabular}{|c|c|c|c|}
\hline $\begin{array}{c}\text { Question } \\
\text { item }\end{array}$ & $\mathbf{r}_{\text {count }}$ & $\mathbf{r}_{\text {table }}$ & $\begin{array}{c}\text { Informatio } \\
n\end{array}$ \\
\hline Mg-1 & 0,651 & \multirow{4}{*}{$\begin{array}{l}\text { The instrument is valid if } \\
\quad r_{\text {count }}>r_{\text {table }} n=91 \\
\text { At the } 10 \% \text { significance } \\
\text { level, the obtained } r_{\text {table }}=\end{array}$} & Valid \\
\hline$\overline{M g-2}$ & 0,730 & & Valid \\
\hline Mg-3 & 0,674 & & Valid \\
\hline $\mathrm{Mg}-4$ & 0,652 & & Valid \\
\hline
\end{tabular}

Source: Output of SPSS version 23

Based on Table above, it can be seen that the item of interest variable for millennial generation is valid. Where $r_{\text {table }}$ is 0.1716 while $r_{\text {count }}$ can be seen in the results of the Corrected Item-Total Correlation and the value of $r$ is positive.

\section{Reliability Test Results}

The results of the reliability test of five variables that have been tested in the validity test, namely the convenience, benefits, trust, risk, and interest of the millinel generation, can be seen in the following tables:

Table 7

Ease of Reliability Test Results

\begin{tabular}{|l|r|r|}
\hline \multicolumn{1}{|c|}{ Variable } & $\begin{array}{c}\text { Cronbach's } \\
\text { alpha }\end{array}$ & \multicolumn{2}{c|}{$\begin{array}{c}\text { N of } \\
\text { Item }\end{array}$} \\
\hline Ease of & 0,679 & 4 \\
\hline Benefit & 0,608 & 4 \\
\hline Trust & 0,640 & 4 \\
\hline Risk & 0,693 & 4 \\
\hline Millennial Generation Interest & 0,604 & 4 \\
\hline
\end{tabular}

Based on the Reliability Statistic tables above, it can be seen that the convenience variable with a Cronbach Alpha value> 0.60 or (0.679>0.60), the benefit variable with a Cronbach Alpha value> 0.60 or (0.608> 0.60), the variable confidence with a Cronbach Alpha value> 0.60 or ( $0.640>0.60)$, the risk variable with a Cronbach Alpha value> 0.60 or (0.693> 0.60), the millennial 
generation interest variable with a Cronbach Alpha value > 0.60 or $(0.640>0.60)$ is reliable. So it can be concluded that the variables in this study are reliable.

\section{Normality Test Results}

Table 12

Normality Test Results

One-Sample Kolmogorov-Smirnov Test

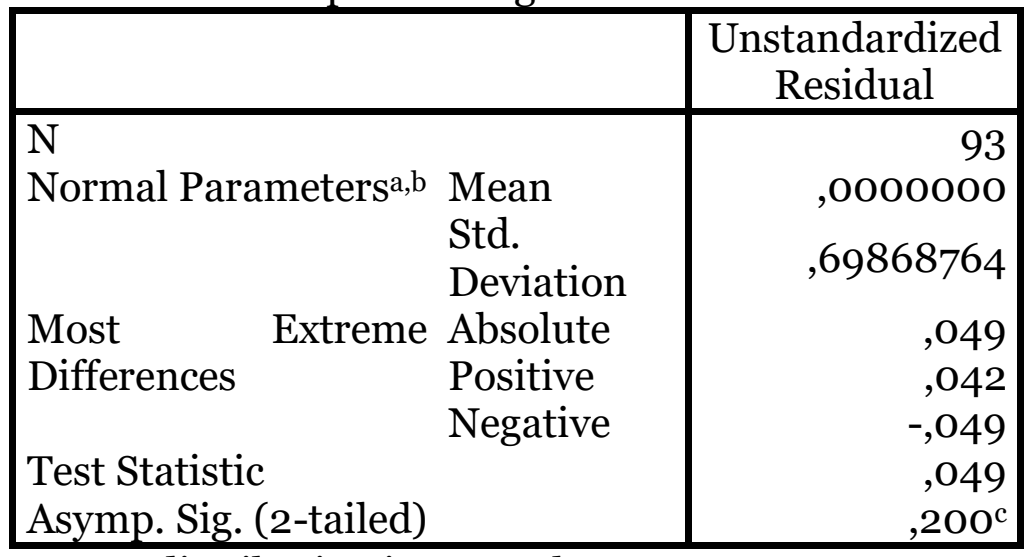

a. Test distribution is Normal.

b. Calculated from data.

c. Lilliefors Significance Correction.

Based on the table above, the sig. > 0.10, then the significant value from the table above is $0.200>0.10$, which means that the Kolmograv Smirnov test is said to be normal.

\section{Classical Assumption Test Results}

\section{a. Multicollinearity Test Results}

A regression model is declared free of multicollinearity if the Variance Inflation Factor VIF $<10$ and the Tolerance value $>0.10$.

Table 13

Multicollinearity Test Results

Coefficients $^{\text {a }}$

\begin{tabular}{|c|c|c|c|c|c|c|c|}
\hline \multirow[b]{2}{*}{ Model } & \multicolumn{2}{|c|}{$\begin{array}{l}\text { Unstandardized } \\
\text { Coefficients }\end{array}$} & \multirow{2}{*}{$\begin{array}{c}\begin{array}{c}\text { Standardized } \\
\text { Coefficients }\end{array} \\
\text { Beta }\end{array}$} & \multirow[b]{2}{*}{$\mathrm{T}$} & \multirow[b]{2}{*}{ Sig. } & \multicolumn{2}{|c|}{ Collinearity Statistics } \\
\hline & B & Std. Error & & & & Tolerance & VIF \\
\hline 1) Constant & ,079 & 1,483 & & ,054 & ,957 & & \\
\hline $\mathrm{Kd}$ & ,484 & , O77 & ,535 & 6,307 & , OOO & ,488 & 2,048 \\
\hline Mf & ,256 & , 074 & ,269 & 3,462 & ,001 &, 582 & 1,718 \\
\hline $\mathrm{Kp}$ & 130 & ,067 & 141 & 1,949 & ,054 & 674 & 1,483 \\
\hline Rs & 104 & ,055 & 114 & 1,897 &, 061 & ,967 & 1.034 \\
\hline
\end{tabular}

a. Dependent Variable: $\mathrm{Mm}$ 


\section{Determinants Of Millenial Generations Interest In Using Mobile Banking \\ Sarmiana Batubara, dkk.}

Based on the table above, it can be seen that the tolerance value of the convenience variable is $0.488>0.10$, the benefit variable is $0.582>0.10$, the trust variable is $0.674>0.10$, and the risk variable is $0.967>0.10$, it can be concluded that the value tolerance of the four variables above is greater than 0.10 (tolerance> 0.10) so that it is free from multicollinearity.

Furthermore, based on the VIF value of the convenience variable is $2.048<10$, the benefit variable is $1.718<10$, the trust variable is $1.483<10$ and the risk variable is $1.034<10$. So it can be concluded that the VIF value of the three variables above is smaller than 10 (VIF value <10) so that it is free from multicollinearity.

\section{b. Heteroscedasticity Test Results}

Picture 2

\section{Heteroscedasticity Test Results}

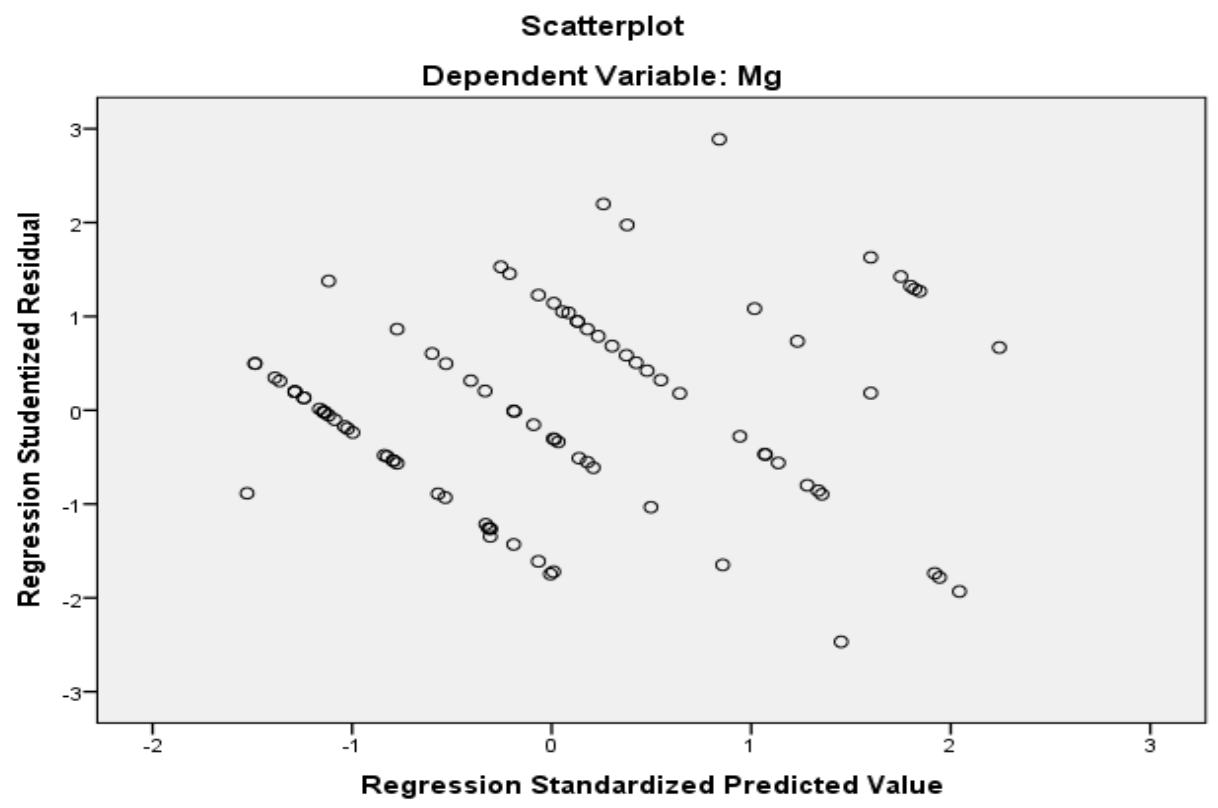

Based on the figure in Figure IV.1 above, it can be seen that the dots do not form a certain pattern. The dots spread above and below the o on the $\mathrm{Y}$ axis. So it can be concluded that the regression model is free from heteroscedasticity. 


\section{Results of Multiple Linear Regression Analysis}

\section{Table 14}

\section{Multiple Linear Regression Analysis Test Results} Coefficients ${ }^{\mathbf{a}}$

\begin{tabular}{|c|c|c|c|c|c|c|}
\hline \multirow{2}{*}{\multicolumn{2}{|c|}{ Model }} & \multicolumn{2}{|c|}{$\begin{array}{l}\text { Unstandardized } \\
\text { Coefficients }\end{array}$} & $\begin{array}{c}\text { Standardized } \\
\text { Coefficients }\end{array}$ & \multirow[b]{2}{*}{$\mathrm{T}$} & \multirow[b]{2}{*}{ Sig. } \\
\hline & & B & Std. Error & Beta & & \\
\hline & (Constant) & , 079 & 1,483 & & , 054 & ,957 \\
\hline & $\mathrm{Kd}$ & ,484 & , O77 & ,535 & 6,307 & , OOO \\
\hline & Mf & ,256 & ,074 & ,269 & 3,462 & ,001 \\
\hline & Kp & 130 & ,067 & 141 & 1,949 & ,052 \\
\hline & Rs & 104 & , 055 & 114 & 1,897 & ,061 \\
\hline
\end{tabular}

a. Dependent Variable: Mm

Based on the table above, it can be seen in the Unstandardized Coefficients column section of column B, the multiple linear regression analysis equation in this study is:

$$
\begin{aligned}
& \mathrm{Mg}=a+\mathrm{b}_{1} \mathrm{Kd}+\mathrm{b}_{2} \mathrm{Mf}+\mathrm{b}_{3} \mathrm{Kp}+\mathrm{b}_{4} \mathrm{Rs}+\mathrm{e} \\
& \mathrm{Mg}=0,079+0,484 \mathrm{Kd}+0,256 \mathrm{Mf}+0,130 \mathrm{Kp}+0,104 \mathrm{Rs}+1,483
\end{aligned}
$$

The regression equation can be explained as follows:

a. A constant of 0.079 means that if the variables of convenience, benefit, trust and risk are considered constant or $\mathrm{o}$, the interest of the millennial generation in using mobile banking at Islamic banks is 0.079 .

b. If the regression coefficient for the convenience variable increases by 1 percent while the other variables are constant, then the interest of the millennial generation in using mobile banking at Islamic banks is equal to.

$$
\begin{aligned}
& =0,484+0,079 \\
& =0,563, \text { then go up } \\
& =0,563 \times 100 \% \\
& =56,3 \%
\end{aligned}
$$

c. If the regression coefficient of the benefit variable increases by 1 percent while the other variables are constant, then the millennial generation's interest in using mobile banking at Islamic Banks is equal to.

$$
\begin{aligned}
& =0,256+0,079 \\
& =0,335, \text { then go up } \\
& =0,335 \times 100 \% \\
& =33,5 \%
\end{aligned}
$$




\section{Determinants Of Millenial Generations \\ Interest In Using Mobile Banking \\ Sarmiana Batubara, dkk.}

d. If the regression coefficient for the trust variable increases by 1 percent while the other variables are constant, then the millennial generation's interest in using mobile banking at Islamic banks is equal to.

$$
\begin{aligned}
& =0,130+0,079 \\
& =0,209, \text { then go up } \\
& =0,209 \times 100 \% \\
& =20,9 \%
\end{aligned}
$$

e. If the risk variable regression coefficient increases by 1 percent while the other variables are constant, then the millennial generation's interest in using mobile banking at Islamic banks is equal to.

$$
\begin{aligned}
& =0,104+0,079 \\
& =0,183, \text { then go up } \\
& =0,183 \times 100 \% \\
& =18,3 \%
\end{aligned}
$$

\section{Result of the coefficient of determination}

Table 15

\section{Determination Coefficient Test Results Model Summaryb}

\begin{tabular}{|l|l|r|r|r|}
\hline $\begin{array}{l}\text { Mode } \\
\mathrm{l}\end{array}$ & $\mathrm{R}$ & $\begin{array}{c}\mathrm{R} \\
\text { Square }\end{array}$ & $\begin{array}{c}\text { Adjusted R } \\
\text { Square }\end{array}$ & $\begin{array}{c}\text { Std. Error of } \\
\text { the } \\
\text { Estimate }\end{array}$ \\
\hline 1 &, $81^{\mathrm{a}}$ &, 691 &, 676 &, 714 \\
\hline
\end{tabular}

a. Predictors: (Constant), Kp, Ma, Km

b. Dependent Variable: Mm

Based on the table above, it is known that the $\mathrm{R}$ square value is 0.691 or $69.1 \%$, this indicates that the variables of convenience, benefits, trust and risk have an effect on the interest variable of the millennial generation in using mobile banking at islamic banks. While the remaining $31.9 \%$ is influenced by other variables not discussed in this study. 


\section{Hypothesis Test Results}

\section{a. T test results}

Table 16

T test results

Coefficients ${ }^{\mathbf{a}}$

\begin{tabular}{|c|c|c|c|c|c|}
\hline \multirow[b]{2}{*}{ Model } & \multicolumn{2}{|c|}{$\begin{array}{l}\text { Unstandardize } \\
\text { d Coefficients }\end{array}$} & \multirow{2}{*}{$\begin{array}{c}\begin{array}{c}\text { Standardized } \\
\text { Coefficients }\end{array} \\
\text { Beta }\end{array}$} & \multirow[b]{2}{*}{$\mathrm{T}$} & \multirow[b]{2}{*}{ Sig. } \\
\hline & B & $\begin{array}{l}\text { Std. } \\
\text { Error }\end{array}$ & & & \\
\hline \begin{tabular}{|ll}
1 & (Constant)
\end{tabular} & ,079 & 1,483 & & ,796 & ,428 \\
\hline $\mathrm{Kd}$ & ,484 & ,077 & ,535 & 6,307 & ,000 \\
\hline $\mathrm{Mf}$ & ,256 & , 074 & 269 & 3,462 & ,001 \\
\hline Kp & 130 & , 067 & 141 & 1,949 & ,054 \\
\hline Rs & 104 & ,055 & ,114 & 1,897 &, 061 \\
\hline
\end{tabular}

a. Dependent Variable: Mm

From the table above, it can be seen that the $t_{\text {count }}$ for the convenience variable is 6.307 for the benefit variable is 3.462 for the confidence variable is 1.949 and for the risk variable is 1.897 . While table with $\mathrm{df}=\mathrm{n}-2$ or $93-2=91$ so that we get table $=1.291$. For more details, see table V.12 below:

Table 17

\section{Summary of partial test results (t test)}

\begin{tabular}{|c|c|c|c|}
\hline Variable & tcount & ttable & Information \\
\hline $\begin{array}{l}\text { Convenience } \\
\text { (X1) }\end{array}$ & 6,307 & \multirow{4}{*}{$\begin{array}{c}\text { ttable }= \\
\mathbf{1 , 2 9 1} \text { with } \\
(\mathbf{d f}=\mathbf{9 1}), \\
\text { and a } \\
\text { significan } \\
\text { ce level of } \\
\text { o.10 }\end{array}$} & $\begin{array}{l}\text { There is an } \\
\text { influence }\end{array}$ \\
\hline Benefits (X2) & 3,462 & & $\begin{array}{l}\text { There is an } \\
\text { influence }\end{array}$ \\
\hline Trust (X3) & 1,897 & & $\begin{array}{l}\text { There is an } \\
\text { influence }\end{array}$ \\
\hline Risk (X4) & 1,662 & & $\begin{array}{l}\text { There is an } \\
\text { influence }\end{array}$ \\
\hline
\end{tabular}

Based on the table above, it can be concluded that the convenience variable, the benefit variable, the trust variable and the risk variable affect the millennial generation's interest in using mobile banking at Islamic banks. 


\section{b. F Test Results}

Table 18

F Test Results

ANOVAa

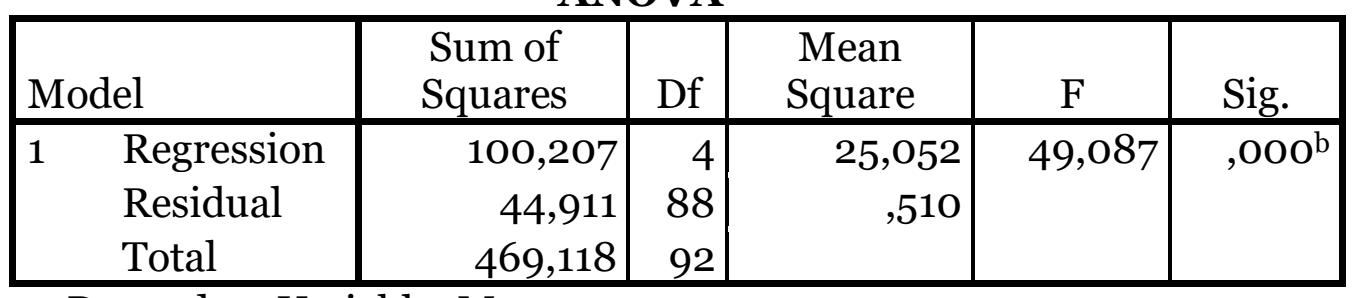

a. Dependent Variable: $\mathrm{Mm}$

b. Predictors: (Constant), Kp, Ma, Km

From the table above, it can be seen that $\mathrm{F}_{\text {count }}$ for the variables of ease, benefit, trust and risk is 49.087. Meanwhile, Ftable with $\mathrm{df}(\mathrm{N} 1)=\mathrm{k}-1$ or $5^{-1}=$ 4 and $\mathrm{df}(\mathrm{N} 2)=\mathrm{n}-\mathrm{k}$ or $93-5=88$ so that $\mathrm{F}_{\text {table }}=2.01$ is obtained. From the results of the $F$ statistical test ( $F$ test), it can be concluded that $F_{\text {count }}>F_{\text {table }}$ (49.087> 2.01), which means that the variables of convenience, benefits, trust and risk simultaneously affect the interest of the millennial generation in using mobile banking at Islamic banks.

Based on the results of the regression analysis carried out in this study, it is known that:

1. Partially ease has an effect on the interest of the millennial generation in using mobile banking, seen from the value of $t_{\text {count }}>t_{\text {table }}(6.307>1.291)$.

Based on the results of the analysis above, it is known that the ease of influencing the interest of the millennial generation in using mobile banking at Islamic banks partially

2. Partially the benefits affect the interest of the millennial generation in using mobile banking, seen from the value of $t_{\text {count }}>t_{\text {table }}(3.462>1.291)$.

Based on the results of the analysis above, it is known that the benefits influence the interest of the millennial generation in using mobile banking at Islamic banks partially.

3. Partially, trust affects the interest of the millennial generation in using mobile banking, as seen from the value of $t_{\text {count }}>t_{\text {table }}(1.949>1.291)$.

Based on the results of the analysis, it is known that trust affects the interest of the millennial generation in using mobile banking at Islamic banks partially. 
4. Partially the risk affects the interest of the millennial generation in using mobile banking, seen from the value of $t_{\text {count }}>t_{\text {table }}(1,897>1,291)$..

Based on the results of the analysis, it is known that risks affect the interest of the millennial generation in using mobile banking at Islamic banks partially.

5. Simultaneously the variables of ease, benefit, trust and risk have an influence on the interest of the millennial generation in using mobile banking which can be seen with the value of $F_{\text {count }}>F_{\text {table }}(49.087>2.01)$.

6. The coefficient of determination of the ease, benefits, trust and risk of the millennial generation's interest in using mobile banking is 69.1\%, while the remaining $31.9 \%$ is influenced by other variables not discussed in this study.

7. Multiple regression analysis obtains the regression equation, namely:

$$
\begin{aligned}
& \mathrm{Mg}=a+\mathrm{b}_{1} \mathrm{Kd}+\mathrm{b}_{2} \mathrm{Mf}+\mathrm{b}_{3} \mathrm{Kp}+\mathrm{b}_{4} \mathrm{Rs}+\mathrm{e} \\
& \mathrm{Mg}=0,079+0,484 \mathrm{Kd}+0,256 \mathrm{Mf}+0,130 \mathrm{Kp}+0,104 \mathrm{Rs}+1,483
\end{aligned}
$$

8. From the multicollinearity test results it is known that the tolerance value $>0.10$ and the VIF value <10, it can be declared free from multicollinearity. Furthermore, the results of the heteroscedasticity test show that the scatterplot points of regression do not form a certain pattern such as spreading above and below the number o on the $\mathrm{Y}$ axis, so it is stated that this regression model does not occur heteroscedasticity.

From the explanation above, it can be seen that the variables of convenience, benefits, trust and risk are factors that influence the interest of the millennial generation in using mobile banking, which means that the easier, more useful, trusting and lower risk the millennial generation has towards mobile banking will increase the interest of the millennial generation in using mobile. banking on Islamic banks.

\section{Conclusion}

Based on the results in this study, there are several factors that influence the interest of the millennial generation in using mobile banking, namely the factors of convenience, benefits, trust and risk. Based on the results of data analysis that has been carried out, the factors of convenience, benefits, trust and risk affect the interest of the millennial generation in using mobile banking at Islamic banks both partially and simultaneously. 


\section{Determinants Of Millenial Generations \\ Interest In Using Mobile Banking \\ Sarmiana Batubara, dkk.}

\section{References}

Amira, D. S., \& Juliani, P. M. (2019). Millenial Investor. Gramedia Widiasarana Indonesia.

Arikunto, S. (2003). Manajemen Penelitian. Rineka Cipta.

Arumi, A., \& Heri Yanto, P. M. P. (2019). Anteseden Penggunaan Layanan Electronic Banking Di Kalangan Mahasiswa. Economic Education Analysis Journal, 8(1), 130-147.

Asosiasi Penyelenggara Jasa Internet Indonesia. (2018). https://apjii.or.id/content/read/104/357/BULETIN-APJII-EDISI-23---April2018.

Basyaib, F. (2007). Manajemen Resiko. Grasindo.

Bungin, B. (2006). Metodologi Penelitian Kuantitatif. Kencana.

Dewi, N. M. A. P., \& Warmika, I. G. K. (2016). Peran persepsi kemudahan penggunaan, persepsi manfaat dan persepsi resiko terhadap niat menggunakan mobile commerce di kota Denpasar [PhD Thesis]. Udayana University.

Fullah, L., \& Candra, S. (2012). Pengaruh Persepsi Manfaat, Kemudahan Penggunaan, Resiko, dan Kepercayaan terhadap Minat Nasabah dalam Menggunakan Internet Banking BRI (Studi Kasus: Seluruh Nasabah Bank BRI Jakarta). Jurnal Manajemen Bisnis Universitas Bina Nusantara, 2(1), 1-10.

Haryanto, A. T. (2019). Pengguna Internet Indonesia Didominasi Milenial. detikinet. https://inet.detik.com/telecommunication/d-4551389/pengguna-internetindonesia-didominasi-milenial.

Hasibuan, M. (2008). Dasar-dasar Perbankan. Bumi Aksara.

Ismail. (2013). Perbankan Syariah. Prenada Media Group.

KOMINFO, P. (2021). Indonesia Raksasa Teknologi Digital Asia. Website Resmi Kementerian Komunikasi Dan Informatika RI. http:///content/detail/6095/indonesia-raksasa-teknologi-digitalasia/o/sorotan_media.

Mappiare, A. (1982). Psikologi Remaja. Usaha Nasional.

Maulana, R., Iskandar, I., \& Mailany, M. (2019). Pengaruh Penggunaan Mobile Banking Terhadap Minat Nasabah dalam Bertransaksi Menggunakan 
Technology Acceptance Model. Cyberspace: Jurnal Pendidikan Teknologi Informasi, 2(2), 146-155.

Nofitasari, D. L. (2017). Analisis Pengaruh Manfaat, Kemudahan Pengguna dan Risiko Terhadap Penggunaan Mobile Banking Bank Syariah di Surakarta: Studi Pada Mahasiswa IAIN SURAKARTA Fakultas Ekonomi dan Bisnis Islam. Skripsi.

Rahmawati, D. (2018). Millennials and I-generation life. Laksana.

Sugara, A., \& Dewantara, R. Y. (2017). Analisis kepercayaan dan kepuasan terhadap penggunaan sistem transaksi jual beli online (Studi pada konsumen "Z"). Jurnal Administrasi Bisnis, 52(1), 8-15.

Sugiyono. (2012). Metode Penelitian Bisnis. Alfabeta.

Supriyono, M. (2010). Buku Pintar Perbankan. Andi.

Yani, E., Lestari, A. F., Amalia, H., \& Puspita, A. (2018). Pengaruh Internet Banking Terhadap Minat Nasabah Dalam Bertransaksi Dengan Technology Acceptance Model. Jurnal Informatika, 5(1), 34-42. 